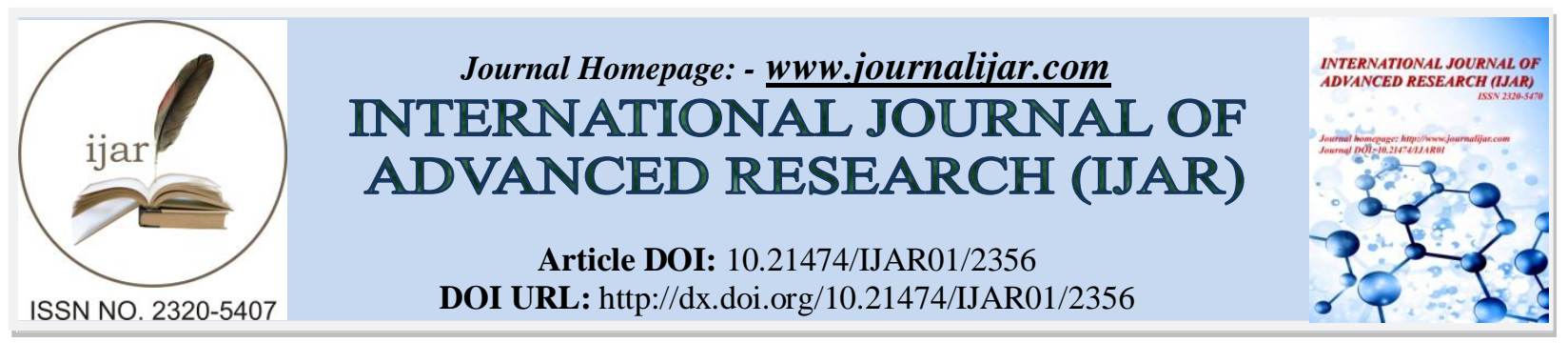

ORIGINAL ARTICLE

\title{
ISLAND DWELLERS PERCEPTIONS ON PADMA RIVER FLOOD
}

Rumana Sultana* and Md. Shafiul Alam.

Department of Geography and Environmental Studies, University of Rajshahi, Bangladesh.

\section{Manuscript Info}

Manuscript History

Received: 02 September 2016

Final Accepted: 25 October 2016

Published: November 2016

Key words:-

Flood, Perceptions, Padma River, Island Dwellers.

\begin{abstract}
Island dwellers' perceptions on flood characteristics were the first determinant of flood distinctiveness. Higher magnitude and duration of flood indicated higher flood susceptibility. The present research was conducted to understand island dweller's perception on Padma river flood. When water level crossed the danger level frequently, it brought a lot of sorrows and sufferings to the present study area. Long duration of flood water implied the severe flood. Similarly, longer duration of flood water enhanced communities flood risk. Two fifth of the respondents said that duration of flood water is usually 21 days to 30 days. Duration of flood water was highest in village Debpur and lowest in village Narayanpur. Duration of flood water was also higher in village Satrashia. In summary, island dwellers' perceived that Padma river flood in the present study area lasted for long time with high magnitude.
\end{abstract}

\section{Introduction:-}

The Ganges is one of world's biggest trans-boundary river systems flowing through India and Bangladesh (Abbas, 1982; Haroun, 1998; Chowdhury, 2003; Hossain et al., 2005). About 400 million peoples are living along the river Ganges locally known as the Padma (Islam, 2011). There is an indivisible relationship between the river Padma and the river bank dwellers (Sultana et al., 2013). By number and economic losses flood disaster is considered to be third of all natural catastrophe throughout the world. More than 520 million people are affected by flood per year in the world. It causes annual deaths of 25,000, homelessness, disaster induced disease, crop and livestock damage and other serious harm (UNU, 2004). Flood is one of the very complex hydrologic processes. Number of sorrows and sufferings are caused by flood. Repetition of flood hazard can solely increase people's vulnerability to flood hazard. Floods inundate a major part of Bangladesh every year from July to September. In a "normal" year approximately 20 percent of the country is affected by overflowing rivers caused by heavy rainfall (Bhuiyan and Baky, 2014). Flooding cause damages crops, infrastructure, island settlements and communication network (Mafizuddin, 1992).Usually in the Gangetic flood occurs when water level cross the danger level.

Most of the studies explain flood characteristics by secondary data. Those results are acceptable for large scale studies but not for small scale studies. It is important to understand local scale flood characteristics in case of small scale studies. The main aim of this study was to understand island dwellers' perception on flood hazard in Narayanpur Mauza. As there is no hydrological station to collect flood data of this Mauza it is needed to combine people's perception and the hydrological data collected from the most nearest station. The present study aimed at understanding island dwellers' perception on flood hazard of Narayanpur Mauza. 


\section{Methodology:-}

Study area:-

The study area, Narayanpur Mauza, lies between $24^{\circ} 30^{\prime} 10^{\prime \prime}$ to $24^{\circ} 33^{\prime} 50^{\prime \prime}$ North latitude and $88^{\circ} 05^{\prime} 10^{\prime \prime}$ to $88^{\circ} 09^{\prime} 40^{\prime \prime}$ East longitude. It is situated in Narayanpur Union in Nawabganj Sadar Upazila which is in Nawabganj district. There are five villages in Narayanpur Mauza: Narayanpur, Satrashia, Madrasa Para, Debpur, and Narayanpur Ghon (Figure 1). Main reason of flooding in this area is the trans-boundary flow from upstream catchment carried by river Ganges. Location disadvantage and socio economic weakness multiplies the negative impacts of flood in this area (Sultana et al., 2013).

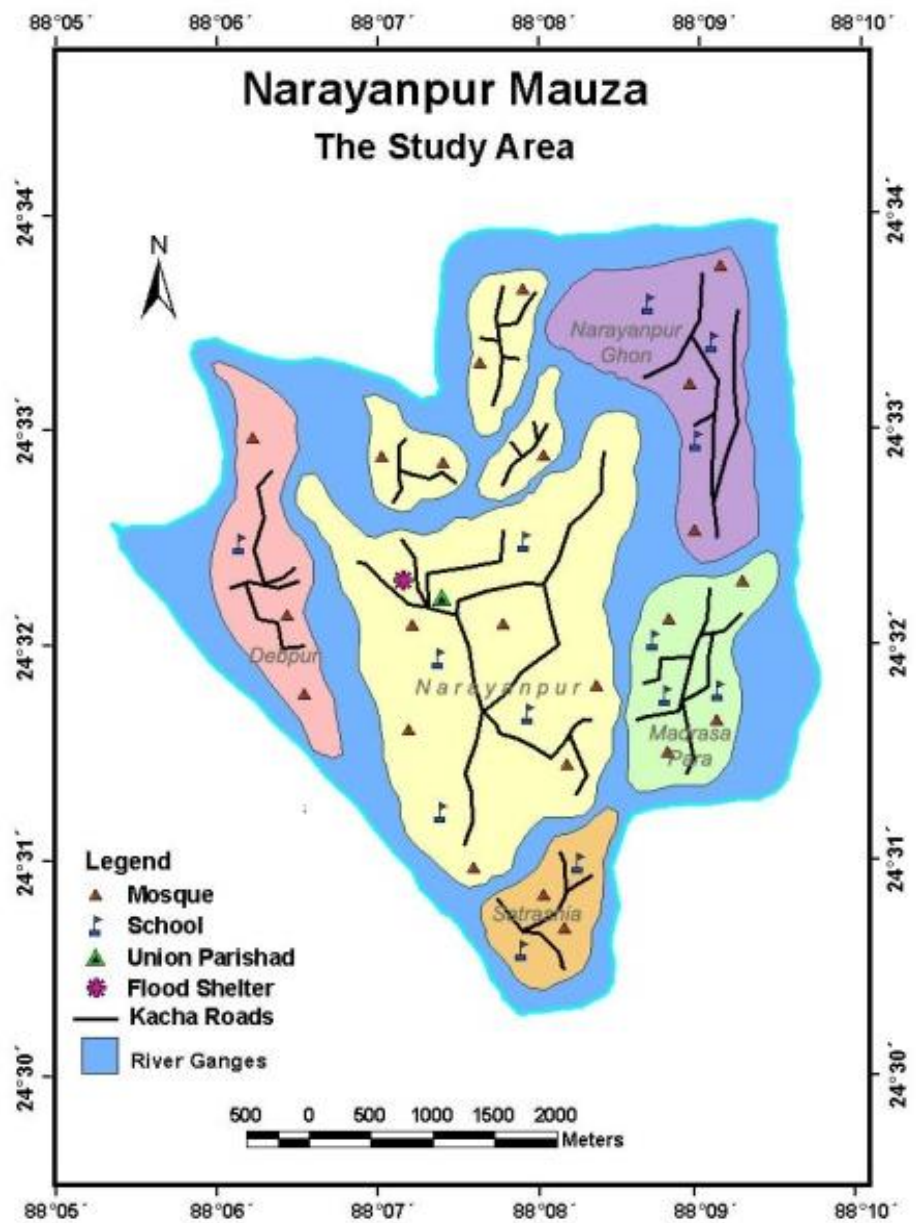

Figure 1:- Study area

\section{Data collection:-}

Secondary data such as Discharge and water level data was collected from Bangladesh Water Development Board (BWDB). Other secondary data were collected from Reports published by BWDB, and Journals, Books, Government and non Government publications. The primary data was collected by performing focus group discussion (there were 30 members in each village) and interviews using questionnaire (randomly selected178 households).

\section{Results and Discussion:-}

\section{People's Perception on Flood:-}

By definition is the potential or existing condition that may cause harm to people or damage to property or environment. People in the flood-prone are have adapt to this situation to cope with the negative impacts of flood. In order to assess flood characteristics in the study are, understanding people's perception is very important. The present research dealt with people's perception on flood magnitude and flood duration. This section discusses the 
magnitude of the flood in the study area based on local people's perception. Information about the magnitude of flood was collected during the fieldwork.

\section{Perception on Flood Magnitude:-}

Magnitude is interrelated to the amount of energy released during the disaster event or flood size. A five point scale is prepared to understand flood magnitudes. According to the focused group discussion the magnitude of flood with a discharge >41000 is very high. This type of flood occurs forty three times between the years 1960 to 2010. During the focus group discussion, island dwellers come to decision that the flood of the year 1972, 2003, 2005, 2007 and 2010 was high magnitude flood (Table 1). Flood of moderate magnitude occurs two times during the year 1960 to2010. They have never experienced the flood of low magnitude.

Table 1:- Flood Frequency of the river Ganges, 1960-2010

\begin{tabular}{|c|c|c|l|}
\hline Magnitude & $\begin{array}{c}\text { Flood } \\
\text { year }\end{array}$ & $\begin{array}{c}\text { Discharge } \\
\text { (Cumec) }\end{array}$ & \multicolumn{1}{|c|}{ Year of occurrence } \\
\hline Very Low & 0 & $<31000$ & \multicolumn{1}{|c|}{} \\
\hline Low & 1 & $31000-32000$ & 1990 \\
\hline Moderate & 2 & $32001-37000$ & 1965,1980 \\
\hline High & 5 & $37001-40999$ & $1972,2003,2005,2007,2010$ \\
\hline Very high & 43 & $>41000$ & $1960,1961,1961,1963,1964,1967,1968,1969,1970,1971$, \\
& & & $\begin{array}{l}1973,1974,1975,1976,1977,1978,1979,1981,1982,1983, \\
\end{array}$ \\
& & & $\begin{array}{l}1984,1985,1986,1987,1988,1989,1990,1991,1992,1993, \\
1994,1995,1996,1997,1998,1999,2000,2002,2004,2005,\end{array}$ \\
\hline
\end{tabular}

Source: Bangladesh Water Development Board, Surface Water Hydrology Department, Dhaka and fieldwork, 2012

\section{People's Perception on Flood Duration:-}

People's perception about duration of flood is analyzed in the Table 2 and Figure 2. Water duration during flood is measured in days. Based on interviews in Narayanpur mauza almost three fifth of the respondents said that the duration of flood water is 21 to 30 days and this category of flood duration shows the highest percentage.

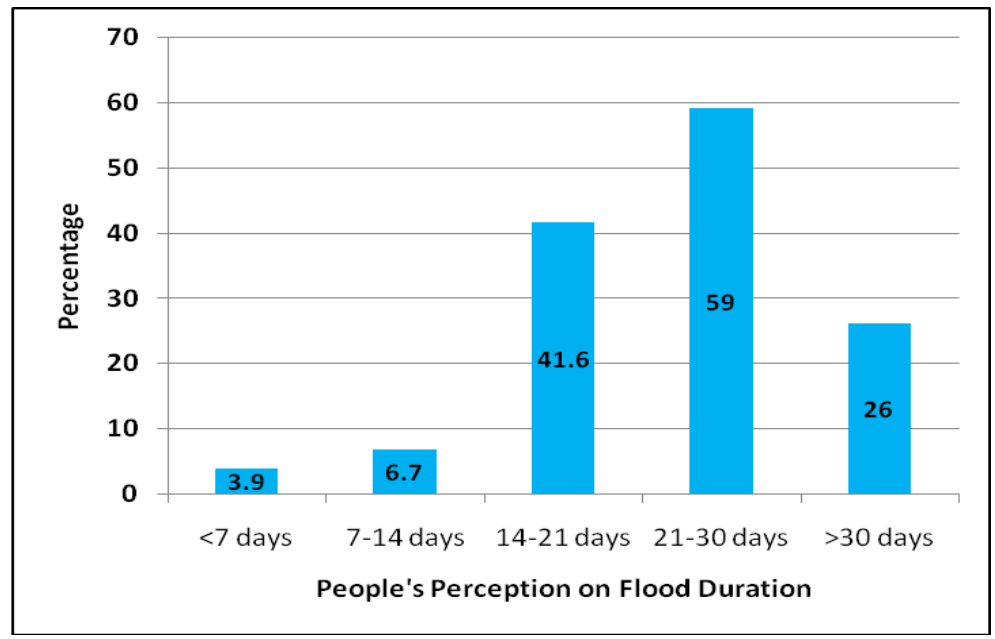

Figure 2:- People's Perception on flood Duration.

The second highest percentage of water duration is 14 to 21 days. Another one fourth of the respondents said that usually water duration is more than 30 years. Among the villages in Narayanpur mauza flood duration more than thirty days shows the highest percentage in Madrasa Para village. Village Satrashia represents the second highest percentage. In village Narayanpur more than half of the respondents said that the duration of flood is 14 to 21 days. Another one third of the inhabitants said that flood duration is more than 30 days. In the village Satrashia more than one third of the respondents said that duration of water is 14 to 21 day and it shows the highest percentage. More than one fifth of the respondents said that duration of water is more than 30 days. In the village Madrasa Para one third of the respondents said that duration of water is 14 to 21 days. Another one fifth said that duration water is 
more than 30 days. In village Debpur half of the respondents said that duration of water is 21 to 30 days and it shows the highest percentage. In village Narayanpur Ghon almost half of the respondents said that duration of flood water is 21 to 30 years and it shows the highest percentage.

Table 2:- People's perception on flood duration

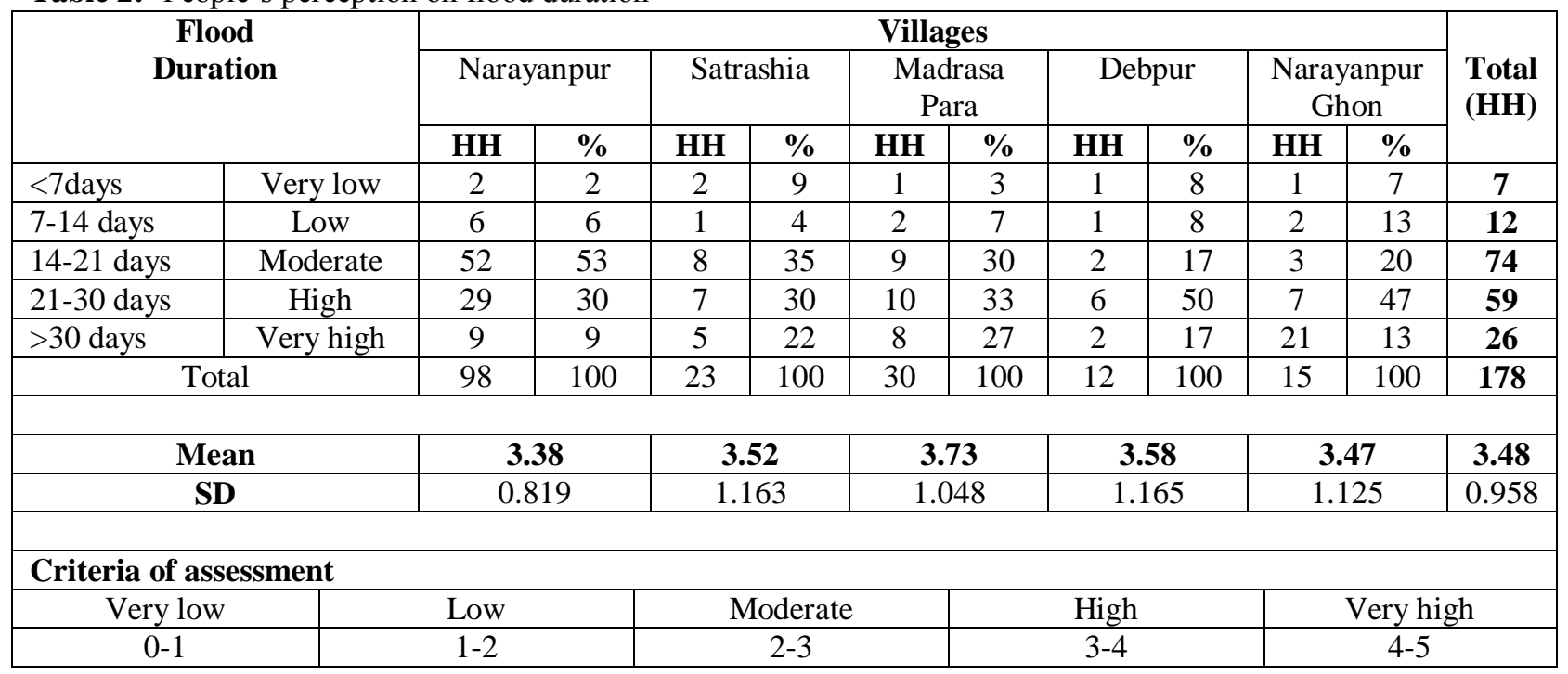

Source: Field Survey, 2012

According to the scored mean value duration of flood water is highest in Madrasa Para. This scored mean value is quiet greater than the mean value of all villages. Duration of flood water is lowest in village Narayanpur. The mean scored value of the village Satrashia, Madrasa Para and Debpur is quiet greater than the scored mean value of all villages. The scored mean value of Narayanpur and Narayanpur Ghon village is less than the mean value of all villages.

\section{Conclusion:-}

Island dwellers' perceptions on flood characteristics are implies higher magnitude and duration of flood that indicates higher flood susceptibility. Long duration of flood water implies the severity of flood. Additionally, longer duration of flood water enhances communities flood risk. Mostly high magnitude flood occurs in this study area. Among all the sites Madrasa Para showed comparatively higher duration of flood. On the other hand, Combination of flood frequency data and island dwellers' perception implies high magnitude and long duration flood in this study area. This pattern of flood is the reason of susceptibility of the island dwellers in this study area.

\section{Reference:-}

1. Abbas, B. M.(1982) : The Ganges Water Dispute. University Press Ltd., Dhaka, Bangladesh.

2. Bhuiyan, S. R., Baky, A. A. (2014) : Digital Elevation based flood hazard and vulnerability study at various return periods in Sirajganj Sadar Upazila, Bangladesh, International Journal of Disaster Risk Reduction, 2014, Vol.10, Part A, pp 48-58, http://dx.doi.org/10.1016/j.ijdrr.2014.06.001

3. Chowdhury, M. H.( 2003) : Padma River. In: Banglapedia the National Encyclopedia of Bangladesh Vol. 5, pp. 217218 , Asiatic Society, Dhaka, Bangladesh.

4. Haroun E. R., Babar K. (1998): Case study: Bangladesh: Water Resources and Population Pressures in the Ganges River Basin. Center for ecology and hydrology.

5. Hossain, M.L., Mahmud, J., Islam, J., Khokon, Z.H., Islam S (eds.) (2005) : Padma, Tatthyakosh Vol. 1 and 2 , , pp. 182 (in Bengali), Dhaka, Bangladesh.

6. Islam, M.S. (2011) : Water sharing issue: Bangladesh India Cooperation, www.thefianancialexpress-bd.com.

7. Mafizuddin, M.(1992) : The physiography of Bangladesh: An overview.In: Elahi K M, Sharif A H M R, Kalam A K A M, eds. BangladeshGeography, Environment and Development. Dhaka: Momin Offset Press, pp20-25

8. Sultana, R., Rumi S. R. A., Sheikh M. A. H. (2013) : Climate Change Induced Flood Risk and Adaptation in the Padma River Island, Bangladesh: A Local Scale Approach, J. Life Earth Sci., Vol. 8, pp 4148, http://dx.doi.org/10.3329/jles.v8i0.20138

9. UNU(2004) : United Nations University Annual report. 